Copyright (C) 2014 by Academic Publishing House Researcher

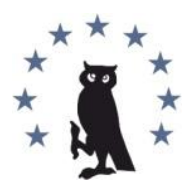

Published in the Russian Federation

European Researcher

Has been issued since 2010.

ISSN 2219-8229

E-ISSN 2224-0136

Vol. 84, No. 10-1, pp. 1742-1746, 2014

DOI: $10.13187 / \mathrm{er} .2014 .84 .1742$

www.erjournal.ru

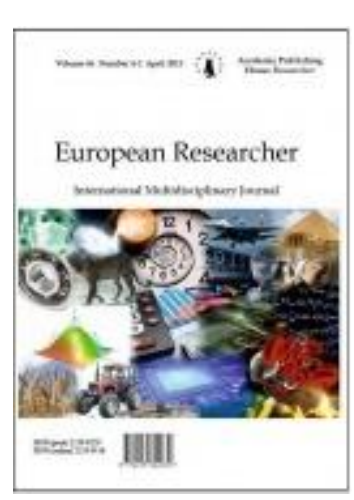

UDC 94

\title{
War as a Social-Psychological Phenomenon
}

\author{
${ }^{1}$ Olga V. Natolochnaya \\ ${ }^{2}$ Vyacheslav I. Menkovsky
}

\begin{abstract}
${ }^{1}$ International Network Center for Fundamental and Applied Research, Russian Federation
${ }^{2}$ Belarusian State University, Belarus

Dr. (History), Professor
\end{abstract}

\section{Abstract}

This article analyzes war as a social-psychological phenomenon. The author dwells upon the difficulties of war veterans' shift from military to peaceful life. The primary sources for this work are letters, diaries, and memoirs by World War II servicemen and veterans. The author concludes the article by pointing out that the capacity for survival in the extreme conditions of the early postwar years had been buoyed up both by post-victory optimism and hopes engendered by it and the need to withstand post-war hardship - an unsettled everyday life, famine, disease, and crime. Amid all this, Soviet society exhibited a great capacity for life, which testified to its considerable mobilization potential.

Keywords: war; psychology; perception of World War II; military-historical anthropology.

\section{Введение}

Литература по истории Великой Отечественной войны настолько обширна, что существует уже не только собственно историография проблемы, но и историография ее историографии. Десятки томов и сотни книг посвящены описанию военных операций и штабной деятельности, выяснению причин первых поражений и последующих побед, изучению военной промышленности и организации работ тыла. История войны, основанная на точных сводках производства танков и самолетов, подсчетах обоюдных потерь, рассуждениях о стратегических выигрышах и ошибках - это, безусловно, необходимая история. Но это история военная, а у войны есть еще и социальное лицо, социальная история, которая не складывается из описания отдельных подвигов на фронте и примеров трудового героизма в тылу. И не потому, что на войне бывало всякое. А скорее так: всякое на войне бывало потому, что война - это жизнь.

\section{Обсуждение}

Такая социальная история войны пока еще слабо прочитывается в исторических трудах. Но она зафиксирована - во фронтовых письмах, дневниках и солдатских мемуарах [1-3], в документальных книгах А. Адамовича, Д. Гранина и С. Алексиевича [4-5], в огромном комплексе писем, интервью, собранных К. Симоновым, в военной прозе писателейфронтовиков - В. Некрасова, В. Астафьева, В. Быкова, Б. Васильева, Г. Бакланова, В. Кондратьева [6-9]. Эти источники, несмотря на то, что они хорошо известны, до сих пор 
не стали предметом специального исторического и историко-психологического исследования.

\section{Результаты}

Без уяснения феномена войны, вошедшего в плоть и кровь поколений, не понять хода последующей истории, механизмов общественного поведения, смены чувств и настроений людей. Поэтому необходимо остановиться на некоторых социально-психологических аспектах войны, которые впоследствии оказали влияние на формирование послевоенной атмосферы.

Официальная пропаганда, основанная на пропаганде идей «малой кровью», «могучим ударом», «Красная Армия всех сильней», постепенно вселила в массовое сознание веру в непобедимость советского оружия. Война виделась победной и непродолжительной. Слова песни «если завтра война...» стали лейтмотивом предвоенной жизни, ее духовным настроем. Шоковое состояние первых дней и месяцев войны было связано даже не столько с фактором «внезапного нападения», сколько с известием об отступлении Красной Армии. Вот к этому и не были готовы ни общество, ни армия, ни сам Сталин. Начался трудный период психологической перестройки, в процессе которой из разрозненных общественных элементов стало постепенно складываться нечто целое, имя которому «воюющий народ». Процесс этот не был одномоментным. Рассуждения о том, что все встали, как один, считает, например, историк Г. Бордюгов, всего лишь очередная мифологема: «Одни пошли сражаться за социализм. Другие думали вовсе не про социализм, а про Отечество. Третьи - службисты, люди системы - были парализованы» [10]. Но для того, чтобы идти в атаку на танки с одной трехлинейкой, политрука впереди и пулеметчика за спиной оказалось мало. Понадобилось нечто совсем иное, что вытекает только из природы человеческого духа, - способность к риску и самопожертвованию. Паралич власти и стратегическую несостоятельность штабов компенсировали духовным порывом народа, стоившим ему миллионных жертв. Такую цену пришлось платить за недееспособность системы.

Со страниц фронтовых писем и дневников война часто предстает не в героическом ореоле, а по-житейски обыденно, как обычная работа. Люди постепенно привыкали к этой новой жизни, на которой даже самое страшное - потеря близкого человека - становилась обычным явлением, и уже не она, а прежняя, довоенная жизнь, казалась им необычной и почти недосягаемой. "Самая большая мечта была на войне - остаться живым $u$ посмотреть, какой будет жизнь после войны», - вспоминает фронтовик-сочинец В.Ф. Цыбанков [11]. Когда же война отодвинулась в прошлое, само восприятие военных лет поднялось на новый уровень.

Психологический поворот, не в последнюю очередь обусловивший и перелом в ходе войны, вырастал на основе преодоления этого парадокса. Война предоставила редкий шанс материализации гражданского чувства народа, которое десятилетиями культивировалось приспособленным к задачам режима, и было привязано к весьма абстрактным, либо далеким от практической жизни понятиям. А здесь оно обрело плоть и кровь конкретной цели - защиты Отечества. Тогда человек ощутил себя гражданином. «На войне я был до необходимости необходим, - вспоминал герой рассказа В. Кондратьева «Знаменательная дата». - И не всяким меня заменить можно было» [12]. Психологическая природа того, что обычно называют гражданским чувством, здесь передана удивительно точно: идет внутренняя переоценка своего «я», которое вырастает до уровня общественной самоценности. А если так, то закономерно увеличивается степень внутренней свободы личности. Не случайно многие фронтовики впоследствии вспоминали, что на войне они чувствовали себя более свободными, чем в мирное время.

Формирование нового взгляда на себя, на мир, на судьбу страны проходило не только под влиянием возросшего чувства личной ответственности, но и в результате осмысления новой информации, которую несла с собой война. Война стала еще и своеобразным каналом общения между людьми, жизненные пути которых в мирное время редко пересекались: на войне встречались деревня и город, недоучившиеся студенты и бывшие заключенные. Разговоры на фронте были весьма откровенными. «Психологический эффект войны заключался в том, что война пробудила в человеке способность вариативно мыслить, 
критически оценивать ситуацию, а не принимать все сущее как единственную данность. Именно эта способность представляла потенциальную опасность для режима, который был рассчитан на субъекта, мыслящего в ограниченных пределах дозволенного» [13].

С войны пришел иной человек, он на многое смотрел другими глазами. Процесс психологической переориентации личности ускорился на последнем этапе войны, когда советский солдат перешагнул границу своей страны и соприкоснулся с другой культурой политической, духовной, экономической. В результате с войны вернулся человек, обладающий опытом и знанием сравнения. «Контраст между уровнем жизни в Европе и $y$ нас, контраст, с которым столкнулисъ миллионы воевавших людей, был нравственным и психологическим ударом», - вспоминал К. Симонов [14].

Вместе с осознанием вариативности бытия и ценности личного выбора война привнесла в мирную жизнь и другое начало, обусловленное особенностями армейского быта: привычку к командованию и подчинению, строгую дисциплину, безусловную силу приказа. «И еще одно плохое пришло с фронта, - пишет фронтовой корреспондент писатель В. Овечкин, - приказал и все, и наплевать, что думают о тебе подчиненные» [15]. На закрепление этой традиции работала государственная структура и политические институты, поэтому для ее развития после войны создавалась атмосфера «наибольшего благоприятствования». Однако и дух свободы, рожденный войной, не мог в этой атмосфере просто раствориться, исчезнуть бесследно: невозможность такого рода «простого» исхода создавала определенный противовес попыткам властей вернуться к довоенному порядку вещей без каких-либо изменений.

В наибольшей степени проблема перехода от войны к миру затрагивала интересы тех, кто был совершенно оторван от мирной жизни, кто четыре года жил как бы в другом измерении, т.е. интересы фронтовиков. Тяжесть потерь, материальные лишения для фронтовиков усугублялись дополнительными трудностями психологического характера, связанными с переключением на новые задачи мирного обустройства. Поэтому демобилизация, о которой так мечталось на фронте, для многих обратилась серьезной проблемой. Прежде всего, для самых молодых, кто ушел на фронт со школьной скамьи, не успев получить профессию. Их единственной профессией стала война, единственным умением - способность держать оружие и воевать. «Война размыла возрастные гранищы, $u$ несколько поколений, заполняя человеческие потери, соединились фактически в одно «поколение победителей», создав, таким образом, новый социум, объединенный общностью проблем, настроений, желаний, стремлений. Конечно, эта общность была относительной, но дух фронтового братства, принесенный с войны, еще долго существовал как важный фактор, влияющий на всю послевоенную атмосферу» [16].

Люди, уставшие разрушать, стремились к созиданию, к миру. Мир на тот момент был высшей ценностью, исключающей насилие в какой бы то ни было форме. «Великая бездомность миллионов людей, именуемая войной, надоедает, - писал с фронта Э. Казакевич, - надоедает не опасностью и риском, а именно этой бездомностью своей» [17]. Проблема дома не только в смысле жилья, а, прежде всего, как проблема жизни, семьи (для многих за годы войны утраченной), становится главной проблемой послевоенного бытия. Ведущей психологической установкой на тот момент для фронтовиков была задача приспособиться к этой жизни, вписаться в нее, научиться жить по-новому. «Мы многое не принимали в системе, но не могли даже представить какой-либо другой», - такое неожиданное признание сделал В. Кондратьев [18]. В нем - отражение характерного противоречия послевоенных лет, раскалывающего сознание людей ощущением несправедливости происходящего и безысходностью попыток этот порядок изменить, поскольку он воспринимался как неизменяемая данность, не зависящая от собственной воли, собственных стремлений и желаний.

С этим настроением фронтовики вошли в мирную жизнь, оставив, как им тогда казалось, за порогом войны самое страшное и тяжелое. Однако действительность оказалась сложнее, совсем не такой, какой она виделась из окопа. «В армии мы часто говорили о том, что будет после войны, - вспоминает журналист Б. Галин, - как мы будем жить на другой день после победы, - и чем ближе было окончание войны, тем больше мы об этом думали, и многое нам рисовалось в радужном свете. Мы не всегда представляли себе размер разрушений, масштабы работ, которые придется провести, чтобы залечить нанесенные 
немцами раны» [19]. «Жизнь после войны казалась праздником, для начала которого нужно было только одно - последний выстрел», - как бы продолжал эту мысль К. Симонов [20].

Иных представлений трудно было ждать от людей, четыре года находившихся под психологическим прессом чрезвычайной военной обстановки, сплошь и рядом состоящей из нестандартных ситуаций. Вполне понятно, что нормальная жизнь, где можно просто жить, не подвергаясь ежеминутной опасности, в военное время виделась, как подарок судьбы. Война в сознание людей - фронтовиков и тех, кто находился в тылу, привнесла переоценку и довоенного периода, до известной степени идеализировав его. Испытав на себе лишения военных лет, люди, часто подсознательно, скорректировали и память о прошедшем мирном времени, сохранив хорошее и забыв о плохом. Желание вернуть утраченное подсказывало самый простой ответ на вопрос «как жить после войны?» - «как до войны».

\section{Заключение}

Обращает на себя внимание непритязательность желаний людей, требующих всего лишь установления прожиточного минимума, и ничего сверх того. Мечты военных лет о том, что после войны «всего будет много» и наступит счастливая жизнь, начали довольно быстро приземляться, девальвироваться, а набор благ, входящих в «предел мечтаний» оскудел настолько, что, зарплата, дающая возможность прокормить семью и комната в коммунальной квартире уже считались подарком судьбы. Но миф о «жизни-сказке», живущий в обыденном сознании и, кстати, поддерживаемый мажорным тоном всей официальной пропаганды, любые трудности преподносящей как «временные», часто мешал адекватному усвоению причинно-следственных связей в цепи волнующихся людей, событий. Поэтому, не находя видимых причин для объяснения «временных» трудностей, которые попадали бы под категорию объективных, люди искали их в привычных чрезвычайных обстоятельствах. Выбор и здесь был не слишком широк. Все трудности послевоенного времени объяснялись последствиями войны.

В этом смысле послевоенное общество можно идентифицировать как социум, ориентированный на выживание. Способность выжить в экстремальной ситуации первых послевоенных лет поддерживалась как послепобедным оптимизмом и порожденными им надеждами, так и необходимостью противостоять послевоенным трудностям - бытовой неустроенности, голоду, болезням, преступности. В этих условиях советское общество продемонстрировало высокую жизнеспособность, что свидетельствовало о его больших мобилизационных возможностях.

\section{Примечания:}

1. Кринко Е.Ф., Тажидинова И.Г. О жизни, смерти и войне: публикация писем и дневников евреев военного времени // Русский архив. 2013. № 1 (1). С. 40-44.

2. Klyushnik I.P. The Notes of a Commandant's Service Company Commander // Voennyi Sbornik, 2014, № 3 (5), pp. 167-174.

3. Dolgopolov T.E. Remarks by Special Operations Soldier // Voennyi Sbornik, 2014, № 2 (4), pp. 80-82.

4. Адамович А., Гранин Д. Блокадная книга. М., 1979.

5. Алексиевич С. У войны не женское лицо. Повести. М., 1988.

6. Бакланов Г. Пядь земли. Повести. Рассказы. М., 1978.

7. Быков В. Дожить до рассвета. Обелиск. Повести. М., 1973.

8. Некрасов В. В окопах Сталинграда. Повесть. Рассказы. М., 1990.

9. Кондратьев В. Сашка. Повести. Рассказы. М., 1989.

10. Украденная победа // Комсомольская правда. 1990. 5 мая.

11. Интервью с Цыбанковым В.Ф. // Личный архив автора.

12. Кондратьев В. Парадоксы фронтовой ностальгии. // Литературная газета. 1990. 5 мая.

13. Зубкова Е. Общество и реформы. 1945-1964. М., 1993. С. 23.

14. Симонов К. Глазами человека моего поколения. Размышления о Сталине // Знамя. 1988. № 3. C. 48 .

15. Овечкин В. Статьи, дневники, письма. М., 1972. С. 203.

16. Зубкова Е. Общество и реформы. 1945-1964. М., 1993. С. 19.

17. Казакевич Э.Г. Слушая время. Дневники, записные книжки, письма. М., 1990. С. 259.

18. Кондратьев В. Не только о своем поколении // Коммунист. 1990. № 7. С. 115. 
19. Галич Б. В одном населенном пункте: рассказ пропагандиста // Новый мир. 1947. № 11. C. 162-163.

20. Симонов К. Собр. соч. в 6-ти томах. Т. 3. М., 1967. С. 124.

\title{
References:
}

1. Krinko E.F., Tazhidinova I.G. O zhizni, smerti i voine: publikatsiya pisem i dnevnikov evreev voennogo vremeni // Russkii arkhiv. 2013. № 1 (1). S. 40-44.

2. Klyushnik I.P. The Notes of a Commandant's Service Company Commander // Voennyi Sbornik, 2014, № 3 (5), pp. 167-174.

3. Dolgopolov T.E. Remarks by Special Operations Soldier // Voennyi Sbornik, 2014, № 2 (4), pp. 80-82.

4. Adamovich A., Granin D. Blokadnaya kniga. M., 1979.

5. Aleksievich S. U voiny ne zhenskoe litso. Povesti. M., 1988.

6. Baklanov G. Pyad' zemli. Povesti. Rasskazy. M., 1978.

7. Bykov V. Dozhit' do rassveta. Obelisk. Povesti. M., 1973.

8. Nekrasov V. V okopakh Stalingrada. Povest'. Rasskazy. M., 1990.

9. Kondrat'ev V. Sashka. Povesti. Rasskazy. M., 1989.

10. Ukradennaya pobeda. //Komsomol'skaya pravda. 1990. 5 maya.

11. Interv'yu s Tsybankovym V.F. // Lichnyi arkhiv avtora.

12. Kondrat'ev V. Paradoksy frontovoi nostal'gii. // Literaturnaya gazeta. 1990. 5 maya.

13. Zubkova E. Obshchestvo i reformy. 1945-1964. M., 1993. S. 23.

S. 48 .

14. Simonov K. Glazami cheloveka moego pokoleniya. Razmyshleniya o Staline // Znamya. 1988. № 3.

15. Ovechkin V. Stat'i, dnevniki, pis'ma. M., 1972. S. 203.

16. Zubkova E. Obshchestvo i reformy. 1945-1964. M., 1993. S. 19.

17. Kazakevich E. G. Slushaya vremya. Dnevniki, zapisnye knizhki, pis'ma. M., 1990. S. 259.

18. Kondrat'ev V. Ne tol'ko o svoem pokolenii. // Kommunist. 1990. № 7. S. 115.

19. Galich B. V odnom naselennom punkte: rasskaz propagandista // Novyi mir. 1947. № 11. S. $162-163$.

20. Simonov K. Sobr. soch. v 6-ti tomakh. T. 3. M., 1967. S. 124.

\section{УДК 94}

\section{Война как социально-психологический феномен}

\author{
${ }_{1}^{1}$ Ольга Васильевна Натолочная \\ ${ }^{2}$ Вячеслав Иванович Меньковский
}

\begin{abstract}
${ }^{1}$ Международный сетевой центр фундаментальных и прикладных исследований, Российская Федерация

Старший научный сотрудник

${ }^{2}$ Белорусский государственный университет, Беларусь

Доктор исторических наук, профессор
\end{abstract}

Аннотация. В статье анализируется война как социально-психологический феномен. Уделено внимание трудностям перехода ветеранов от военной к мирной жизни. Основным источником для написания работы послужили письма, дневники и мемуары военнослужащих и ветеранов Великой Отечественной войны. В заключении автор отмечает, что способность выжить в экстремальной ситуации первых послевоенных лет поддерживалась как послепобедным оптимизмом и порожденными им надеждами, так и необходимостью противостоять послевоенным трудностям - бытовой неустроенности, голоду, болезням, преступности. В этих условиях советское общество продемонстрировало высокую жизнеспособность, что свидетельствовало о его больших мобилизационных возможностях.

Ключевые слова: война; психология; восприятие Великой Отечественной войны; военно-историческая антропология. 